\title{
Changes in Microbial and Functional Properties of Lima Bean (Phaseolus lunatus) Flour During Storage
}

\author{
Elizabeth O. Farinde \\ Institute of Agricultural Research and Training, Obafemi Awolowo University, \\ PMB 5029, Ibadan, Nigeria
}

\begin{abstract}
Lima bean is a nutritious food legume. In addition to nutritional value of food product, its keeping quality and functional properties during storage are also important in determining the quality of the food for consumption. The study aimed at evaluating the microbial and functional properties of lima bean flour during storage. Lima bean was processed into flour, packaged in low density polyethylene bag and stored at ambient $\left(28 \pm 2{ }^{\circ} \mathrm{C}\right)$ temperature for twenty-four weeks. The stored samples were evaluated for microbial (Total viable count and mold count) and functional properties (Bulk density, water and oil absorption capacity, foaming capacity, emulsion capacity and dispersibility). Total viable count (TVC) increased from $1.60 \mathrm{log} \mathrm{cfu} / \mathrm{g}$ at week 0 to $4.25 \mathrm{log} \mathrm{cfu} / \mathrm{g}$ at week 24 of storage. There was no mold growth till week 12 of storage. Mold count increased from $1.77 \log \mathrm{cfu} / \mathrm{g}$ in week 12 to $3.77 \mathrm{log} \mathrm{cfu} / \mathrm{g}$ in week 24 . Both TVC and mold counts in the lima flour were far lower than the recommended limit of $10^{6} \mathrm{cfu} / \mathrm{g}$ for TVC and $10^{3} \mathrm{cfu} / \mathrm{g}$ for mold count respectively by International Microbiological Standards. There was no significant difference $(p>0.05)$ in the bulk density of the lima bean flour at storage. Water absorption capacity, oil absorption capacity, foam capacity, emulsion capacity and dispersibility decreased slightly with storage time. The study showed that lima bean flour is safe for consumption and can serve as a potential functional food ingredient in food products formulation without much changes in its functional properties over a period of twenty-four weeks.
\end{abstract}

Keywords: Lima bean flour, Functional properties, microbial properties, storage, safety.

DOI: $10.7176 / \mathrm{FSQM} / 107-05$

Publication date: April $30^{\text {th }} 2021$

\section{Introduction}

Inadequate protein and calorie supply coupled with increasing population growth are still posing problems of malnutrition in Nigeria (Awan, 2000; Ezeagu and Ibegu, 2010). Legumes also known as pulses have been found to be important food protein and energy sources. They belong to the family Leguminosae. They are inexpensive with high nutritional profile. Legumes have protein content ranging from $17-40 \%$, much higher than that in cereals (7-11.8\%) and comparable to the protein content of meat, 18 - $25 \%$ (De Oliveira, 2006). They are important source of protein and calorie in tropical and subtropical regions where they play important roles in traditional diets (Chung et al., 2008; Okafor et al., 2002). They are referred to as major or minor legumes depending on their popularity, discovery and extent of utilization. Some of the underutilized legumes in developing countries particularly Africa, include pigeon pea, jack bean, sword bean, gram pea, moth bean, mungo bean, winged bean, velvet bean, kidney bean, lima bean, African yam bean, black gram and bambara groundnut (Fasoyiro et al., 2005; Habibullah et al., 2007; Bamishaiye et al., 2011; Olanipekun et al., 2015; Nimenibo-Udia, 2017; Farinde et al., 2017). These minor legumes can be used to fill the gap created by high cost of staples, animal proteins, and commonly eaten plant protein sources like cowpea and soya beans (Olanipekun et al., 2015).

Lima bean is a nutritious food legume containing between 21 to $24 \%$ protein, 0.7 to $2.9 \%$ fat, 5.2 to $5.8 \%$ crude fibre, 4.3 to $5.4 \%$ Ash and 52 to $62 \%$ carbohydrate (Farinde et al., 2011; Fasoyiro et al., 2006; Yellavila et al., 2015). Lima beans are good source of minerals such as potassium, phosphorus, sodium, calcium, iron, copper and zinc (Farinde et al., 2011). They are also a very good source of B vitamins such as vitamin B6, niacin, thiamine, and riboflavin. The behavior of protein in a food system is very important in its functional properties. Lima beans are rich in protein and have appreciable functional properties that could be exploited in food formulations (Yellavila et al., 2015). The factors that affect functional behavior of proteins in foods are their size, shape, amino acid composition and sequence as well as interaction with other food constituents (Moses et al., 2012). Functional properties are determined in foods to know the effect of processing on the protein in the food and interaction of protein in raw and finished food products (Onimawo and Akubor, 2005).

Food products should not only be nutritious, but they must also be safe for consumption (Fasoyiro et al, 2010). Keeping quality of flour for a long time is very paramount in order to prevent hazards such as mold, bacteria, oxidative rancidity, and changes in functional as well as sensory properties during storage of the product (Shobha et al., 2014). Ibeanu et al. (2015) reported that molds were found in seed flour mixes used for infant feeding from the $14^{\text {th }}$ day of storage. Unacceptable levels of mold growth in flours do not only cause health risks, but also nutritional and economic losses of the product (Fasoyiro et al., 2016). Hence, the need to evaluate the microbial and functional properties of lima bean flour during storage for its safety and quality as a potential functional food 
ingredient in food products formulation informed this study.

\section{Materials and Methods}

\subsection{Processing of Lima Bean into Flour and Storage}

Lima bean (Phaseolus lunatus) seeds (light brown variety) were purchased from a local market at Ita-Ogbolu, via Akure, Ondo State, Nigeria. Fasoyiro et al. (2016) method for processing of pigeon pea into flour was used for lima bean flour processing with slight modifications. Lima beans $(1 \mathrm{~kg})$ were soaked in water $(1: 3 \mathrm{w} / \mathrm{v})$ for $2 \mathrm{~h}$ and then blanched in boiling water for 20 minutes. The blanched seeds were washed under running water to cool the beans down to room temperature $\left(28 \pm 2^{\circ} \mathrm{C}\right)$. The seeds were then mechanically dehulled by shredding $250 \mathrm{~g}$ of the seeds in $250 \mathrm{ml}$ of water for $30 \mathrm{sec}$ in a blender (Kenwood BL440, UK). Hulls were removed by washing the lima bean seeds with water, floating off the hulls and sieving. The dehulled lima beans were allowed to drain for about 30 min after which the beans were spread on aluminum tray, and dried at $60{ }^{\circ} \mathrm{C}$ for $12 \mathrm{~h}$ in hot air oven (Gallenhamp, OV-160) to a moisture content of $8 \%$. The dried lima beans were milled into flour to pass through a $0.25 \mathrm{~mm}$ sieve.

The Lima bean flour was packed $(100 \mathrm{~g} / \mathrm{pack})$ in low density polyethylene (LDPE) bags and stored at ambient condition $\left(28 \pm 2^{\circ} \mathrm{C}\right)$ for a period of 6 months $(24$ weeks). Samples were analyzed at interval of two weeks initially for one month after which the samples were evaluated at interval of four weeks (monthly) up to period of 24 weeks of storage. Samples were evaluated for microbial and functional properties during storage.

\subsection{Microbial Determination}

Microbial determination of the lima bean samples was carried out using the method described by Farinde et al. (2017) and Amankwah et al. (2009). Lima bean flour (1 g) was aseptically transferred into sterile peptone water $(9 \mathrm{~mL})$ in sterile stomacher bag and homogenized in a stomacher (Colworth Stomacher 400 model 6021, London) for 30 seconds. This gave a dilution of $10^{-1}$. The suspension was serially diluted in sterile peptone water until appropriate dilution was obtained (Harrigan, 1998). Nutrient agar (NA) and Sabouraud dextrose agar (SDA) media were prepared according to the manufacturer's instructions and sterilized in an autoclave at $121^{\circ} \mathrm{C}$ at $15 \mathrm{psi}$ pressure for 15 minutes. Aliquot $(1.0 \mathrm{ml})$ of appropriately diluted sample was plated in triplicates in the media using the pour plate method. NA was used for enumeration of bacteria while SDA was used for enumeration of molds. Nutrient agar plates were incubated at $35^{\circ} \mathrm{C} \pm 2{ }^{\circ} \mathrm{C}$ aerobically for $24 \mathrm{~h}$ while SDA plates were incubated at $28{ }^{\circ} \mathrm{C} \pm 2{ }^{\circ} \mathrm{C}$ for 3 days. Colonies were counted at the end of incubation using colony counter. Colonies were expressed as colony forming units per gram $\left(\mathrm{cfu} \mathrm{g}^{-1}\right)$ of the sample.

\subsection{Functional Properties}

\subsubsection{Bulk Density}

The bulk density (BD) of the lima bean flour samples was determined using the method described by Onwuka (2005). Ten grams $(10 \mathrm{~g})$ of the sample was weighed into $50 \mathrm{ml}$ graduated measuring cylinder. The sample was packed by gently tapping the cylinder on the bench top from a height of $5 \mathrm{~cm}$ ten times. The volume of the sample in the measuring cylinder was recorded. Bulk density $(\mathrm{g} / \mathrm{ml})$ was expressed as the weight of the sample divided by the volume of sample after tapping

\subsubsection{Dispersibility}

Dispersibility of the lima bean flour sample was determined using the method described by Ohizua et al. (2017). Ten grams of sample was suspended in $200 \mathrm{ml}$ measuring cylinder and distilled water was added to reach the $100 \mathrm{ml}$ mark. The set up was stirred vigorously and allowed to settle for $3 \mathrm{~h}$. Dispersibility was obtained by subtracting the volume of the settled particles from 100 .

Dispersibility $=100-$ volume of settled particle

2.3.3. Water and Oil Absorption Capacity

Water absorption capacity (WAC) and oil absorption capacity (OAC) of the lima bean flour samples were determined following the methods described by Ojukwu et al. (2012). Two gram ( $2 \mathrm{~g})$ of sample was mixed with $20 \mathrm{ml}$ distilled water for water absorption and $20 \mathrm{ml}$ of oil for oil absorption. Each mixture was blended in a blender (Kenwood BL440, UK) at high speed for $30 \mathrm{~s}$. Samples were allowed to stand at $30^{\circ} \mathrm{C}$ for 30 min and then centrifuged at $10000 \mathrm{x}$ g for $30 \mathrm{~min}$. The volume of supernatant was measured in a graduated cylinder. Density of water was taken to be $1 \mathrm{~g} / \mathrm{ml}$ and that of oil to be $0.93 \mathrm{~g} / \mathrm{ml}$.

Water absorption capacity (WAC) percent was calculated as:

WAC $\%=\frac{\text { Amount of water added-volume of supernatant } x \text { density of water }}{\text { weight of sample }} \times 100$

And that of oil as: 
OAC $\%=\frac{\text { Amount of oil added-volume of supernatant } x \text { density of oil }}{\text { Weight of sample }} \times 100$

\subsubsection{Emulsion Capacity}

Emulsion capacity of the lima bean flour sample was determined using the method described by Eke (2002). To 2 $\mathrm{g}$ of sample was added $75 \mathrm{ml}$ distilled water, the mixture was blended for $30 \mathrm{~s}$ and stirred on a magnetic stirrer until complete dispersion was obtained. Deodorized vegetable oil was added continuously through a burette until emulsion breakpoint was reached (separation into two layers). The emulsion capacity was expressed as volume of oil emulsified per $\mathrm{g}$ of flour.

Emulsion capacity $=\frac{\text { Volume }(m L) \text { of oil }}{\text { Gramme of sample }}$

\subsubsection{Foaming Capacity}

The foaming capacity of the lima bean flour samples were determined according the method described by Onwuka (2005). Two grams (2 g) of samples was blended with $100 \mathrm{~mL}$ distilled water for $30 \mathrm{~min}$. The mixture was transferred into a $250 \mathrm{~mL}$ measuring cylinder and the volume after $30 \mathrm{~s}$ was recorded. The foam capacity was expressed as percent increase in volume calculated as:

FC $\%=\frac{\text { Volume after } \text { whipping-volume before whipping }}{\text { Volume before whipping }} \times 100$

\subsection{Statistical Analysis}

Data obtained were subjected to descriptive and inferential statistics (ANOVA) using SPSS (version 20 incorporation, Chicago, Illinois, USA). Means of samples were separated using Duncan Multiple range Test. Significance was accepted at $5 \%$ level (Kibar and Kibar, 2017)

\subsection{Results and Discussion}

3.1 Microbial Count of Lima Bean Flour During Storage

Total viable count (TVC) is a quantitative estimate of concentration microorganisms such as bacteria, yeasts and molds spores in food stuffs and food products. A high TVC count in a food product is an indication of a high concentration of micro-organisms which may subsequently indicate poor quality of the food. The storage ability of a food product is also related to the quantity of microorganism present in the food (NZFSA, 2005). The result of the Total viable count (TVC) of the lima bean flour during storage is shown in Figure 1. Total viable count increased from $1.60 \mathrm{log} \mathrm{cfu} / \mathrm{g}$ at Week 0 to $4.25 \mathrm{log} \mathrm{cfu} / \mathrm{g}$ at week 24. Multiplication and growth of microorganism with storage time was gradual and not very significant between week 2 and week 8 , the increase was also gradual between week 12 and week 20 but there was a significant increase in week 24.The increase in TVC of the stored lima bean flour might be due to post production contamination and moisture absorption during storage. Awoyale et al. (2015) similarly reported increase in total viable count during storage of custard powder. Tiwani et al. (2018) and Raja et al. (2014) also reported increase in total viable count with storage time in malted 'ragi' flour stored for 90 days and blends of mixed rice, black gram, peanut flour and fish carbs stored for a period of 28 days at ambient respectively. However, the total TVC recorded for the lima bean flour after 24 weeks of storage in this study was still within the limit of $<10^{6} \mathrm{cfu} / \mathrm{g}$ recommended by the International Microbiological Standards.

There was no mold growth in the lima bean flour sample until after 8 weeks of storage (Figure 2). Mold count gradually increased from $1.77 \mathrm{log} \mathrm{cfu} / \mathrm{g}$ at week 12 to $3.77 \mathrm{log} \mathrm{cfu} / \mathrm{g}$ at week 24. Fasoyiro et al. (2016) similarly 

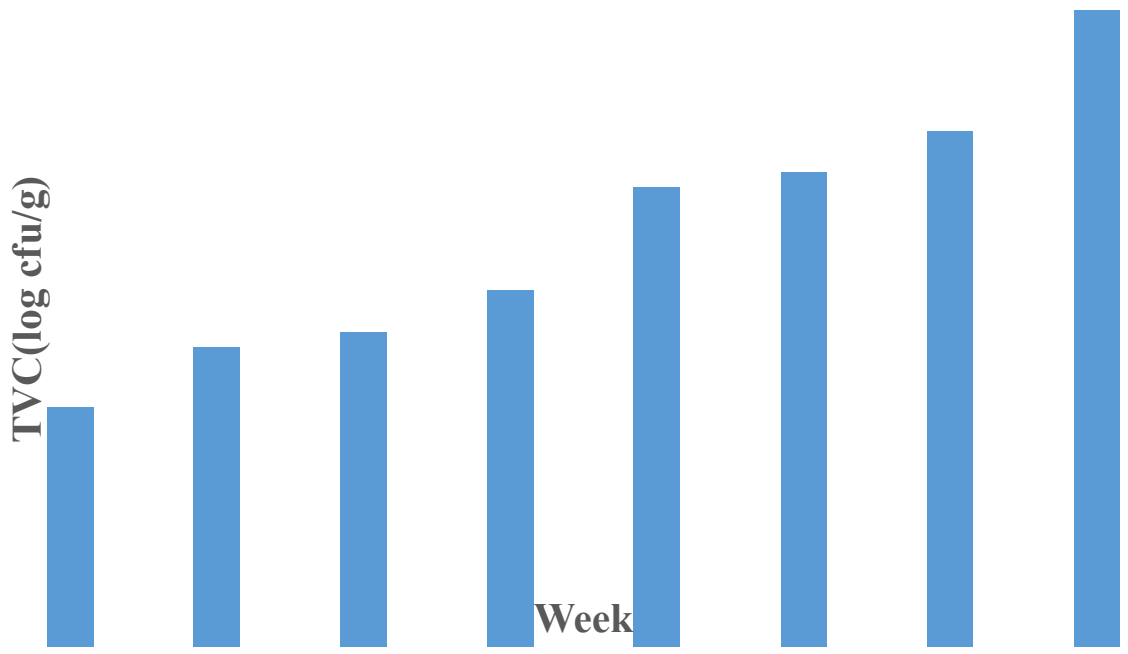

Figure 1: Total viable count of Lima bean flour during storage
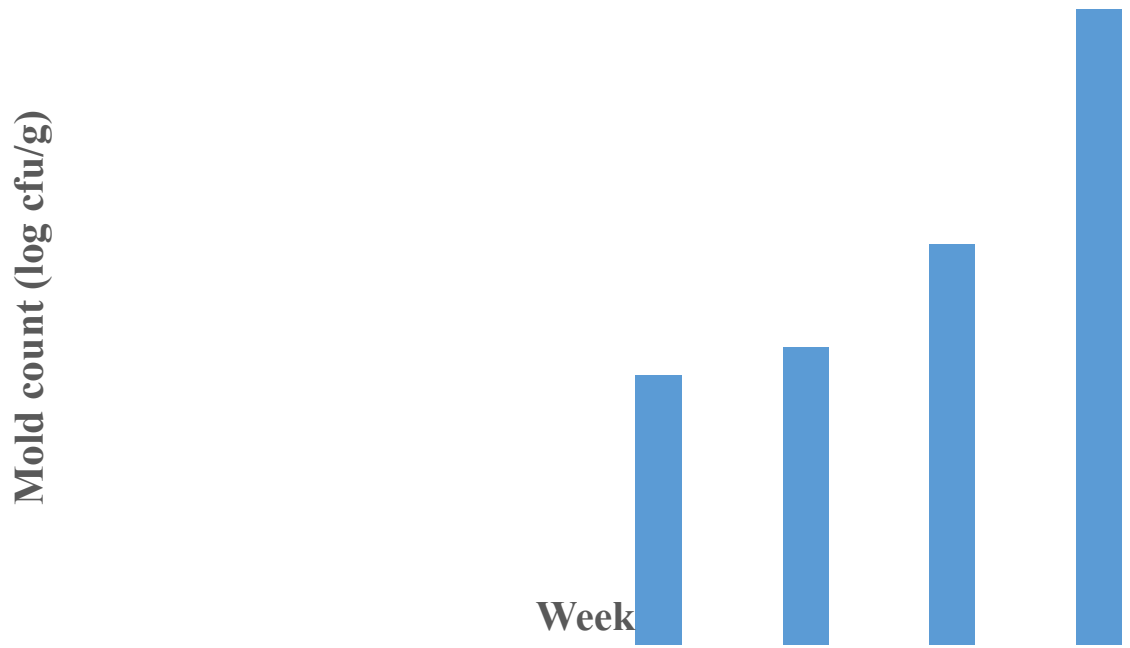

Figure 2: Mold count of Lima bean flour during storage

reported initial slight increase in the fungi population in stored maize-pigeon pea fortified flour from 1.69 log $\mathrm{cfu} / \mathrm{g}$ to $2.45 \log \mathrm{cfu} / \mathrm{g}$ after 8 weeks of storage. Raja et al. (2014) also reported nil growth for mold up till the $3^{\text {rd }}$ week in stored mixed rice, black gram and peanut flour with fish carb. Absence of mold growth till later part of the storage period in the lima bean flour sample might be due to the powdery nature of the sample and the air tight condition of the packaging (low density polyethylene). The sharp increase after 20 weeks of storage could be due to moisture absorption afterwards. However, the values were less than the recommended limit of $10^{3} \mathrm{cfu} / \mathrm{g}$ prescribed by the International Microbiological Standards (Shobha et al. 2011) and ICMSF (1996) specifications of $10^{5} \mathrm{cfu} / \mathrm{g}$ for flours.

\subsection{Functional Properties of Lima Bean Flour During Storage}

Results of the functional properties of the lima bean flour samples during storage are presented in Table 1. There was no significant difference $(p>0.05)$ in the bulk density of the lima bean flour samples at storage. There was a slight increase in the bulk density from $0.64 \mathrm{~g} / \mathrm{ml}$ at week 1 to $0.65 \mathrm{~g} / \mathrm{ml}$ at week 2 of storage, after which the bulk density of the samples remained static (unchanged) till week 12 of storage. The bulk density then decreased slightly to $0.64 \mathrm{~g} / \mathrm{ml}$ till the end of the storage period. Adetuyi et al. (2009) similarly reported reduction in the bulk density of germinated flour after a period of 12 weeks. Shohba et al. (2014) also reported that there was no change in bulk density of the lime treated quality protein maize flour up to 3 months of storage. Bulk density is an important parameter that determines the packaging requirement of a product. It signifies the behaviour of a product in dry mixes and may vary with fineness of particles (Butt and Batool, 2010). The result of the bulk density in this 
study showed that the lima bean flour could still retain its bulk density during storage with little or no changes. The low bulk density of the lima bean flour at storage in this study makes it a potential useful ingredient for preparing nutrient dense foods particularly complementary foods. Low bulk density has been reported as an advantage in the formulation of complementary foods (Nwagbaoso et al., 2018).

Table 1: Functional properties of Lima bean flour during storage

\begin{tabular}{lllllll}
\hline Week & BD $(\mathrm{g} / \mathrm{ml})$ & $\begin{array}{l}\text { WAC } \\
(\mathrm{g} / 100 \mathrm{~g})\end{array}$ & $\begin{array}{l}\text { OAC } \\
(\mathrm{g} / 100 \mathrm{~g})\end{array}$ & FC (\%) & EC (\%) & DP (\%) \\
\hline 1 & $0.64 \pm 02^{\mathrm{a}}$ & $124.3 \pm 02^{\mathrm{a}}$ & $97.5 \pm 07^{\mathrm{a}}$ & $6.8 \pm 01^{\mathrm{a}}$ & $12.3 \pm 07^{\mathrm{a}}$ & $47.7 \pm 04^{\mathrm{a}}$ \\
2 & $0.65 \pm 04^{\mathrm{a}}$ & $124.0 \pm 01^{\mathrm{a}}$ & $95.4 \pm 02^{\mathrm{a}}$ & $6.3 \pm 01^{\mathrm{a}}$ & $11.4 \pm 07^{\mathrm{a}}$ & $44.03 \pm 11^{\mathrm{a}}$ \\
4 & $0.65 \pm 04^{\mathrm{a}}$ & $122.9 \pm 01^{\mathrm{a}}$ & $93.6 \pm 07^{\mathrm{a}}$ & $5.6 \pm 04^{\mathrm{b}}$ & $10.5 \pm 02^{\mathrm{b}}$ & $42.4 \pm 11^{\mathrm{a}}$ \\
8 & $0.65 \pm 01^{\mathrm{a}}$ & $121.9 \pm 02^{\mathrm{a}}$ & $93.0 \pm 02^{\mathrm{a}}$ & $4.4 \pm 01^{\mathrm{b}}$ & $8.8 \pm 01^{\mathrm{c}}$ & $38.9 \pm 10^{\mathrm{b}}$ \\
12 & $0.65 \pm 01^{\mathrm{a}}$ & $121.5 \pm 01^{\mathrm{a}}$ & $85.3 \pm 10^{\mathrm{b}}$ & $4.2 \pm 07^{\mathrm{b}}$ & $7.9 \pm 07^{\mathrm{d}}$ & $35.17 \pm 02^{\mathrm{b}}$ \\
16 & $0.64 \pm 01^{\mathrm{a}}$ & $118.7 \pm 11^{\mathrm{b}}$ & $81.2 \pm 04^{\mathrm{c}}$ & $4.0 \pm 07^{\mathrm{c}}$ & $7.9 \pm 02^{\mathrm{d}}$ & $32.12 \pm 04^{\mathrm{b}}$ \\
20 & $0.64 \pm 04^{\mathrm{a}}$ & $116.3 \pm 09^{\mathrm{b}}$ & $80.1 \pm 04^{\mathrm{d}}$ & $3.7 \pm 02^{\mathrm{c}}$ & $6.9 \pm 02^{\mathrm{e}}$ & $30.10 \pm 11^{\mathrm{c}}$ \\
24 & $0.64 \pm 02^{\mathrm{a}}$ & $113.6 \pm 11^{\mathrm{c}}$ & $78.4 \pm 10^{\mathrm{e}}$ & $3.5 \pm 01^{\mathrm{d}}$ & $6.5 \pm 10^{\mathrm{f}}$ & $28.15 \pm 10^{\mathrm{c}}$ \\
\hline
\end{tabular}

Means followed by the same superscript are not significantly different at $p>0.05$

BD - Bulk density, WAC - Water absorption capacity, OAC - Oil absorption capacity

FC - Foam capacity, EC - Emulsion capacity, DP- Dispersibility

Water absorption capacity (WAC) decreased slightly with storage in the lima bean flour. The water absorption capacity decreased from $125.3 \mathrm{~g} / 100 \mathrm{~g}$ at week 1 to $113.6 \mathrm{~g} / 100 \mathrm{~g}$ at 24 weeks of storage. There was no significant difference $(p>0.05)$ in the water absorption capacity of the lima bean flour up to $12^{\text {th }}$ week of storage and just slight decrease till the end of the storage period. This coincided with the microbial growth which showed just slight increase till $12^{\text {th }}$ week of storage. Shobha et al. (2012) similarly reported decreased in water absorption capacity of lime treated and untreated QPM flour over storage. Water absorption capacity shows the ability of a product to associate with water under conditions where water is limiting. Flours with high water absorption have more hydrophilic constituents, such as polysaccharides (Yellavila et al., 2015). Water absorption capacity of flour plays an important role in food preparation because it influences texture and sensory properties. The legume flours containing several water-loving components, such as polysaccharides and hydrophilic proteins generally have high water absorption capacity and impart soft texture to cereal-based foods (Singh, 2001) Water absorption capacity affects products cohesiveness due to interaction of protein with water for properties such as hydration, swelling, solubility and gelation. (Onimawo and Akubor, 2005). Paul and Ayernor (2002) stated that water absorption capacity depends on protein content, nature and type of proteins in the food material and that the higher the protein content the higher the water absorption capacity. Slight reduction in the water absorption capacity of the lima bean flour with storage may be due to utilization of protein by the microorganisms causing reduction in the protein content and subsequently the WAC. However, the water absorption capacity of the stored lima bean flour samples is still high enough to impact positively on the texture of food products that may be developed from the lima bean flour especially when combined with other flour such as cereal flour for composite food formulation.

Oil absorption capacity (OAC) decreased from 97.5 at week 1 to $78.4 \mathrm{~g} / 100 \mathrm{~g}$ at week 24 of storage. Despite the slight decrease in OAC, the oil absorption capacity was still high enough to make it a good food base for other food formulation. There was no significant difference $(\mathrm{p}>0.05)$ in the oil absorption capacity of the lima bean flour up to week 8 of storage. This is in line with the mold count in the lima bean flour, in which there was nil count till after 8 weeks of storage. Oil absorption capacity range in this study is close to the range reported by Ohizua et al. (2017) for pigeon pea-banana flour blend. Legume flours with high oil absorption capacity are used in foods to impart desired texture and mouth feel. High oil absorption capacity of the lima bean flour may likely be due to hydrophobic character of protein in the flour as presence of protein exposes more non-polar amino acids to fat thus improving oil absorption of the flour. (Oluwalana et al., 2011). Protein in foods influences fat absorption (Ajani et al., 2016) and this is of benefit because lima bean is very low in fat, hence its' been high in oil absorption capacity will improve the texture and taste of products developed from the lima bean flour especially when combined with other flour for food formulation. Fat has been found to improve the texture and flavour of baked products and also gives feeling of satiety (Nnam and Obiakor, 2003).

Foam capacity (FC) decreased from $6.8 \%$ at week 1 to $3.5 \%$ at week 24 of storage. There was no significant difference $(\mathrm{p}>0.05)$ in the foam capacity of the lima bean flour sample at week 1 and 2 . There was also no significant difference $(p>0.05)$ in the foam capacity of the lima bean flour sample from week 4 to week 12 . Foam capacity is related to the interfacial film formed by proteins, which maintain air bubbles in suspension and slows down the rate of coalescence. It is influenced by protein and carbohydrate composition of the flour (Dossou et al. 2014; Sreerama, et al., 2012). Lima bean flour in this study recorded low values compared with $14.36 \%$ to $20.30 \%$ for different lima beans flour reported by Ekpo and Ugbenyen (2011). The low foam capacity of lima bean flour may be attributed to the globular nature of storage proteins in the beans. Proteins, which exhibit low foam capacity, may not be suitable for food products that require a high percentage of porosity such as cakes but may be good for 
products with more plasticity such as semolina from composite mixture of lima bean four and maize flour.

Emulsion capacity (EC) decreased from $12.3 \%$ at week 1 to $6.5 \%$ at week 24 of storage. Emulsion capacity is the ability of protein to absorb at the interfacial area of oil and water in an emulsion (Yellavila et al., 2015). Emulsion capacity is the maximum oil required for water-oil phase separation (Onimawo and Akubor, 2005). Proteins are surface active agents and can form emulsion by creating electrostatic repulsion on oil droplet surfaces (Kaushal et al., 2012). The EC reported in this study was lower than the EC in green gram flour reported by Kaushal et al. (2012). Increase in the total viable count and mold count especially at the later stages of storage might be responsible for the decrease in the emulsion capacity as the protein content must have reduced.

Dispersibility of the lima bean flour also decreased with storage time. It decreased from $47.7 \%$ to $28.15 \%$. Dispersibility measures the extent that flour or flour blends can be rehydrated with water (Kulkarni et al. 1991) and may help to determine fine constituent of dough during mixing (Ramashia et al., 2018). Dispersibility of a flour also shows its protein solubility in water. Reduction in dispersibility of the lima bean flour with storage may be associated with the increase in total viable count with storage which might have subsequently decreased the protein content of the flour.

\section{Conclusion}

Total viable count and mold counts recorded in the lima bean flour during storage for 24 weeks were far lower than the limit recommended by International Microbiological Standards, making the product safe. The lima bean flour retained its bulk density with little changes during storage, an indication that packaging will be economical and the flour could be useful for producing high nutrient dense foods. Although water absorption capacity, oil absorption capacity foaming capacity, emulsion capacity and dispersibility of the lima bean flour decreased slightly with storage time, the values obtained for these parameters are still high enough for a food ingredient, moreover, the flour is a primary product which potentially will be combined with other flour or ingredients for improved functional properties. Lima bean flour is safe for consumption; its functional properties remained relatively stable over a storage period of 24 weeks. Lima bean flour can therefore serve as a functional food ingredient which can be used in food formulation and product development.

Further studies should be carried out on the microbial and functional properties of the flour for a much longer period.

\section{Acknowledgement}

The author is grateful to Institute of Agricultural Research and Training, Ibadan for funding the research.

\section{References}

Adetuyi, F. O., Badejo, O. F., Ikujenlola, A. V. \& Omosuli, S. V. (2009). Storage influence on the functional properties of malted and unmalted maize (Zea mays L ssp mays) and soybean (Glycine max L Merrill) flour blends. African Journal of Food Science. 3(2), 56 - 60.

Ajani, A. O., Fasoyiro, S. B., Arowora, K. A., Ajani, O. O., Popoola, C. A. \& Zaka, K. O. (2016). Functional Properties of Composite Flour made from Wheat and Breadfruit. Applied Tropical Agriculture, 21 (2), 89-93.

Amankwah, E. A., Barimah, J., Nuamah, A. K. M., Oldham, J. H. \& Nnaji, C. O. (2009). Formulation of weaning food from fermented maize, rice, soybean and fishmeal. Pakistan Journal of Nutrition, 8,1747-1752.

Awan, J. A. (2000). Elements of Food and Nutrition (2nd ed.). Faisalabad, Pakistan, Pakistan: Uni-tech Communications.

Awoyale, W., Sanni, L. O., Shittu, T. K. A. \& Adegunwa, M. O. (2015). Effect of storage on the chemical composition, microbiological load, and sensory properties of cassava starch- based custard powder. Food Science and Nutrition, 395, $425-433$.

Bamishaye, O. M., Adegbola, J. A. \& Bamishaye, E. I. (2011). Bambara groundnut: an underutized nut in Africa. Advances in Agricultural Biotechnology, 1, 60 - 72

Butt, S.M. \& Batool, R. (2010). Nutritional and Functional Properties of Some Promising Legumes Protein Isolates. Pakistan Journal of Nutrition, 9, 373-379.

Chung, H., Liu, Q., Peter, P., Ming, Z. \& Rickey, Y. (2008). In vitro starch digestibility, expected glycemic index and some physicochemical properties of starch and flour from common bean (Phaseolus vulgaris L.) varieties grown in Canada. Food Research International, 111(2), 316-321

De Oliveira, A. C. (2006). Chemical composition, dietary fibre and resistant starch contents of raw and cooked pea, common bean, chickpea and lentil legumes. Food Chemistry, 94, 327-330.

Dossou, V.M., Agbenorhevi, J. K., Alemawor, F \& Oduro, I. (2014). Physicochemical and Functional Properties of full fat and defatted Ackee (Blighiasapida) Aril Flours. American Journal of Food Science and Technology, 2(6), 187-191.

Ekpo, K. E \& Ugbenyen, A. M. (2011). Comparative evaluation of certain functional properties of four different varieties of Lima Bean (PhaseolusLunatus) flour, Annals of Biological Research, 2(2), 399-402. 
Ezeagu, I. E. \& Ibegu, M. D. (2010). Biochemical composition and nutritional potential of ukpa: A variety of tropical lima beans (Phaseoluslunatus) from Nigeria - A short report. Polish Journal of Food and Nutrition Sciences, 60(3), 231-235.

Farinde, E. O., Adeniran, H. A. \& Abiose, S. H. (2011). Proximate composition, mineral content and sensory assessment of an iru analogue produced from lima bean (Phaseoluslunatus). Ife Journal of Technology. 20(2), $1-6$

Farinde, E. O., Obatolu, V. A. \& Fasoyiro, S. B. (2017). Microbial, Nutritional and Sensory Qualities of Baked Cooked and Steamed Cooked Lima Beans. American Journal of Food Science and Technology, 5(4), 156161

Fasoyiro S. B, Obatolu V. A, Ashaye O. A, Adegoke G. O. \& Farinde, E. O. (2010). Microbial hazards of locally processed soy-cheese in Nigeria. Nutrition and Food Science, 40, 591-597

Fasoyiro, S. B., Ajibade, S. R., Omole, A. J., Adeniyan, O. N. \& Farinde, E. O. (2006). Proximate, minerals and anti-nutritional factors of some underutilized grain legumes in South-Western Nigeria. Nutrition and Food Science. 36(1), $18-23$.

Fasoyiro, S. B., Ajibade, S. R., Saka, J. O., Ashaye, O. A., Obatolu, V. A., Farinde, E. O. \& Afolabi, O. O. (2005). Physical characteristics and effect of processing methods on pigeon pea varieties. Journal of Food, Agriculture and Environment. 3(3), 59 -61.

Fasoyiro, S., Hovingh, R., Gourama, h. \& Cutter, C. (2016). Change in water activity and fungal counts of maizepigeon pea flour during storage using various packaging materials. Procedia Engineering, 159, 72 - 76.

Habbullah, A., Abas, M. \& Sha, H. U. (2007). Proximate and mineral composition of mung bean. Sarhad Journal of Agriculture, 23(2), $464-466$

Harrigan, W. F. (1998). Laboratory Methods in Food and Dairy Microbiology Academic Press, New York.

Ibeanu, V. N., Ene-Obong, H. N., Peter-Ogba, G. U. \& Onyechi, U. A. (2015). Microbiological evaluation and shelf life of seed mixes used in infant feeding in rural northern Nigeria. 14(20), 1718-1723

ICMSF (1996). International Commission on Microbiological Standards for Foods. Microorganisms in Foods, Characteristics of microbial pathogens. Gaithersburg, Aspen Publishers Inc.

Kaushal, P., Kumar, V. \& Sharma, H. K. (2012). Comparative study of physicochemical, functional, antinutritional and pasting properties of taro (Colocasiaesculenta), rice (Oryzasatva) flour, pigeon pea (Cajanuscajans) flour and their blends. LWT-Food Science Technology, 48, 59-61

Kulkarni, K. D., Kulkarni D. N. \& Ingle W. M. (1991). Sorghum malted and soybean weaning food formulation: preparation, functional properties and nutritive value. Food Nutrition. Bulletin, 13, 322-329.

Moses, O., Olawuni, I. \& Iwouno, J. O. (2012). Proximate Composition and Functional Properties of Full-Fat Flour, and Protein Isolate of Lima Bean (Phaseolus lunatus). Scientific Report 1(7), 349 - 354

Nimenibo-Udia, R. I. (2017). Preliminary studies on Canavalia ensiformis (Jack bean) seeds. Proximate analysis and phytochemical screening. Science World Journal, 12(2), $59-62$

Nnam, N. M. \& Obiakor, P. N. (2003). Effect of fermentation on the nutrient and antinutrients compositionn of baobab (Adansonia digitata) seeds and rice (Oryza sativa) grains. Ecology Food and Nutrition. 42, 265-277.

Nwagbaoso, O. C., Okoronkwo, K. A. \& Awah, A. I (2018). Investigation into the Functional and Sensory Properties of Two Varieties of Local Black Beans (Phaseolus Vulgaris) Flour. IOSR Journal of Environmental Science, Toxicology and Food Technology (IOSR-JESTFT), 12 (7), 39-45

NZFSA, (2005). Guide to calculating the shelf life of foods, Food Safety Authority of New Zealand, NZFSA, http://www.nzfsa.govt.nz/processed-food-retail-sale/shelflife/shelflife1-2-2.pdf, New Zealand.

Ohizua, E. R, Adeola, A. A., Idowu, M. A., Olajide, P., Sobukola, 1. T., Afolabi, A., Ishola, R. O., Ayansina, S. O., Oyekale, T.O. \& Falomo, A. (2017). Nutrient composition, functional, and pasting properties of unripe cooking banana, pigeon pea, and sweet potato flour blends. Food Science and Nutrition, 5(3), 750 - 762.

Ojukwu, M., Olawunmi, I. \& Iwuono, I. O. (2012). The proximate composition and functional properties of full fat flour and protein isolate of lima bean (Phaseolus lunatus). Open Access Scientific Report. 1, 1 - 5

Okafor, P. N., Aabara, C. N., Nwabuko, C. U. \& Ogbonna, U. (2002). Assessment of cyanogenic potential, nitrate and nitrite contents, and trypsin inhibitor activity of some Nigerian legumes. Journal of Agriculture and Food Chemistry, 50, 4965-4968

Olanipekun O. T.1., Olapade O. A., Suleiman P.1.\& Ojo, S. O. (2015). Nutrient and sensory analysis of abari made from composite mixture of kidney bean flour and maize flour. Sky Journal of Food Science, 4(2), 19 -23

Oluwalana I. B., Oluwamukomi M. O., Fagbemi T. N. \& Oluwafemi G. I. (2011). Effects of temperature and period of blanching on the pasting and functional properties of plantain (Musa Parasidiaca) flour. Journal of Stored Products and Postharvest Research, 2, 164-169.

Onimawo, I. A. \& Akubor, P. I. (2005). Functional properties of food. In: Food Chemistry. Integrated Approach with Biochemical Background. Ambik Press Limited, Benin City, Nigeria. Pp 208-221

Onwuka, G. I. (2005). Food analysis and instrumentation: Theory and Practice. Naphthali prints, Lagos, Nigeria, pp 63-161. 
Paul, H. \& Ayernor, G. S. (2002). Appropriate processing and food functional properties of maize flour. African Journal of Science Technology, 3, 126-131.

Raja, W. H., Kumar, S., Bhat, Z. F. \& Kumar, P. (2014). Effect of ambient storage on the quality characteristics of aerobically packaged fish curls incorporated with different flours. Springer Plus, 3, 106 -116.

Ramashiaa, S. E., Gwatab, E. T., Meddows-Taylorc, S., Anyasia, T. A. \& Jideania, A. I. O. (2018). Some physical and functional properties of finger millet (Eleusinecoracana) obtained in sub-Saharan Africa. Food Research International, 104, 110-118.

Shobha, D., Prasanna, K., Puttaramanaik, M. K. \& Sreemasetty, T. A. (2011). Effect of Antioxidant on the Shelf Life of Quality Protein Maize Flour. Indian Journal Fundamental and Applied Life Science, 1, 129-140.

Shobha, D., Dileepkumar, V., Sreeramasetty, T. A., Puttaramanaik, K. T., PandurangeG, \& Shivakumar, G. B. (2014). Storage influence on the functional, sensory and keeping quality of quality protein maize flour. Journal of Food Science and Technology, 51(11), 3154-3162.

Singh, R. B., Dubnor, G., Niaz, M. A., Gosh, S., Singh, R., Rastogi, S. S., Manor, O., Pella, D. \& Berry, E. M. (2002). Effect of an indo-mediterranean diet on progression of coronary heart disease in high risk patients. Lancet, 360, 1344-1455.

Singh, U. (2001). Functional properties of grain legume flours. Journal of Food Science and Technology, 38:191199.

Sreerama, Y. N., Sashikala, V. B., Pratape, V. M., \& Singh, V. (2012). Nutrients and antinutrients in cowpea and horse gram flours in comparison to chickpea flour: evaluation of their flour functionality. Food Chemistry, 131, 462-468.

Tiwari, S., Sarkar, N. \& Singh, A. (2018). Nutritional Quality, Functional Property and Storage Potential of Malted Ragi Flour. Journal of Pharmaceutical, Chemical and Biological Sciences. 6(3), 276-281

Yellavila, S. B., Agbenorhevi, J. K., Asibuo, J. Y. \& Sampson, G. O. (2015) Proximate Composition, Minerals Content and Functional Properties of Five Lima Bean Accessions. Journal of Food Security, 3(3), 69-94. 